\title{
Big oyster, robust echinoid: an unusual association from the Maastrichtian type area (province of Limburg, southern Netherlands)
}

\author{
Stephen K. Donovan ${ }^{1,2} \cdot$ John W. M. Jagt ${ }^{3}$
}

Received: 27 February 2018/Accepted: 10 May 2018/Published online: 1 June 2018

(C) Akademie der Naturwissenschaften Schweiz (SCNAT) 2018

\begin{abstract}
Large, denuded tests of holasteroid echinoids were robust benthic islands in the Late Cretaceous seas of northwest Europe. A test of Hemipneustes striatoradiatus (Leske) from the Nekum Member (Maastricht Formation; upper Maastrichtian) of southern Limburg, the Netherlands, is encrusted by a large oyster, Pycnodonte (Phygraea) vesiculare (Lamarck). This specimen is a palaeoecological conundrum, at least in part. No other members of the same oyster spatfall attached to this test and survived. Indeed, only two other, much smaller bivalve shells, assignable to the same species, attached either then or somewhat later. The oyster, although large, could have grown to this size in a single season. The larval oyster cemented high on the test and this would have been advantageous initially, the young shell being elevated above sediment-laden bottom waters. However, as the oyster grew, the incurrent margin of the commissure would have grown closer to the sediment surface. Thus, the quality of the incurrent water probably deteriorated with time.
\end{abstract}

Keywords Late Cretaceous $\cdot$ Pycnodonte $\cdot$ Hemipneustes $\cdot$ Taphonomy $\cdot$ Palaeoecology

\section{Introduction}

Large holasteroid echinoids, such as the genera Echinocorys Leske, 1778, Cardiaster Forbes, 1850, and Hemipneustes Agassiz, 1836, in the Upper Cretaceous of northern Europe were important both in life, as common components of the vagile benthos (Schmid 1949; Nestler 1965; Jagt 2000; Smith and Wright 2002, 2003) and postmortem, where they formed benthic 'islands' that were important substrates for a range of encrusting and boring organisms (compare Nebelsick et al. 1997; Belaústegui

Editorial Handling: Daniel Marty.

Stephen K. Donovan

Steve.Donovan@naturalis.nl

John W. M. Jagt

john.jagt@maastricht.nl

1 Taxonomy and Systematics Group, Naturalis Biodiversity Center, Postbus 9517, 2300 RA Leiden, The Netherlands

2 Department of Earth Sciences, University of New Brunswick, Fredericton, NB E3B 5A3, Canada

3 Natuurhistorisch Museum Maastricht, de Bosquetplein 6-7, 6211 KJ Maastricht, The Netherlands et al. 2013, 2017). Associations on holasteroid tests may be monospecific or nearly so, such as dense accumulations of pits assigned to Oichnus Bromley, 1981 (see, for example, Donovan and Jagt 2002; Hammond and Donovan 2017; Donovan et al. 2018), or include two or more distinct taxa (see, for example, Jagt et al. 2012). Rarely does a test bear a solitary encruster or boring; commonly, there may be tens of individuals, small in size, closely associated and often in a regular pattern ('Inkrustationszentrum' of Schmid 1949). Further, in life, these were undoubtedly supplemented by unmineralized invertebrate taxa, and possibly algae and fungi, which have left no recognizable fossil record.

So, the subject of the present communication is an unusual specimen in more ways than one. It is a large holasteroid encrusted by a single oyster that attained large size. The oyster is cemented in an elevated position and in an orientation which invites interpretation. In short, this specimen is considered to be an instructive example that allows us to gaze, albeit dimly, into one small corner of the benthic environment of the Late Cretaceous sea. 


\section{Locality and horizon}

The specimen is part of the Brock-Meessen Collection at the Natuurhistorisch Museum Maastricht, the Netherlands (Jagt 2011) and bears the registration number NHMM BM MK.151. It was collected, possibly, when the conveyor belt was still in operation (see Mulder et al. 2016), from quarry 't Rooth (formerly Nekami) at Bemelen, southern Limburg (Felder and Bosch 2000, pp. 85-86, 106, figs. 3.42, 4.4; Fig. 1 herein), originating from the upper third of the Nekum Member (Felder and Bosch 2000, fig. 3.48) of the Maastricht Formation, Consequently, it is of late Maastrichtian age (Jagt 1999a, pp. 29-30; Jagt and Jagt-Yazykova 2012, p. 17, table 1).

\section{Description}

NHMM BM MK.151 is a test of the large holasteroid echinoid Hemipneustes striatoradiatus (Leske, 1778), measuring about $88.7 \mathrm{~mm}$ in length, $82.7 \mathrm{~mm}$ in width and $63.5 \mathrm{~mm}$ in height. The test has a broad, flat oral surface; a high anterior region with the apical system anterior of centre and the highest point of the test more anterior still. The more posterior test slopes posteriorly; the anterior test is steep (Fig. 2c, d). The test is cracked on both the oral and apical surfaces (Fig. 2) and was undoubtedly dead on the seafloor - a benthic island (compare Nestler 1965; Nebelsick et al. 1997; Belaústegui et al. 2013)—at the time of encrustation (Donovan 1991).

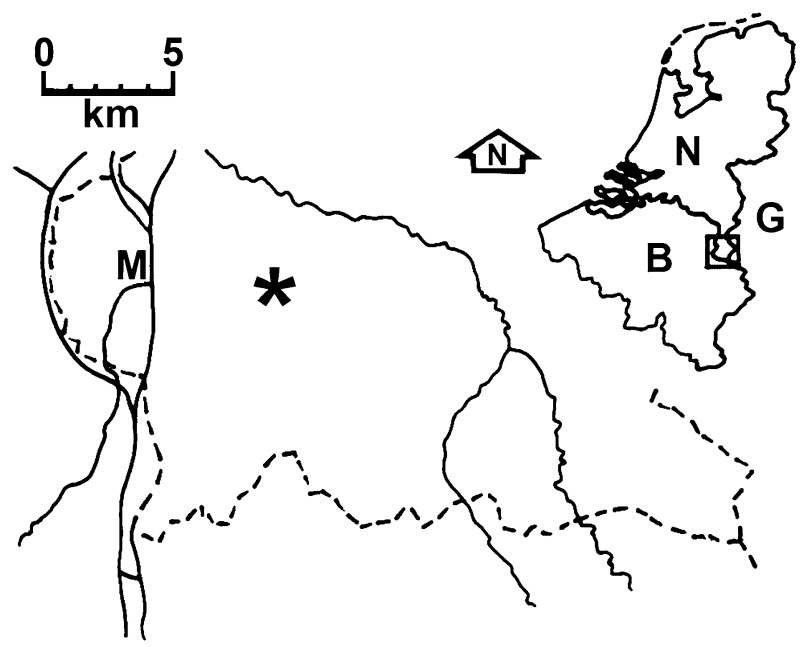

Fig. 1 Outline map of study area (redrawn and simplified after Jagt 1999b, fig. 1). Key: dashed lines = political boundaries; solid lines = rivers and canals; $\mathrm{M}=$ city of Maastricht; asterisk = quarry ' $t$ Rooth, Bemelen. For more detailed locality maps of this region, see Jagt and Jagt-Yazykova (2012, fig. 1) and, particularly, Felder and Bosch (2000, fig. 3.42). The inset map of the Netherlands (N), Belgium (B) and Germany $(G)$ shows the approximate position of the main map (box)
Cemented to the echinoid test on the apical system, and with its dorsal margin oriented almost perpendicular to the long axis of the echinoid (Fig. 2a), is the attached valve of the pycnodonteine oyster Pycnodonte (Phygraea) vesiculare (Lamarck, 1806) (Stenzel 1971; Cleevely and Morris 2002, p. 147, pl. 24, figs. 8-10; Fig. 2 herein). This is a particularly large specimen for an endoskeletozoan (sensu Taylor and Wilson 2002; it is convenient to here recall that the echinoid test is an endoskeleton) from these deposits, about $57 \times 54 \mathrm{~mm}$. The ligament pit is triangular and flanked by a triangular dentition on each side (edentulous denticulate dentition; Skelton 1985, table 6.4.1), and a solitary, moderately large adductor muscle scar within the pallial line. The commissure is curved and raised up above the surface of the echinoid test (Fig. 2a, d).

Other endoskeletozoans are small to minute and some may have been lost by cleaning after collection. The largest of these are seen in the shallow depression of the anterior ambulacrum (amb III) of the echinoid, near the apex of the test; these are two incomplete cemented valves of conspecific oysters that are presumed to represent either failed members of the same spat fall as the large oyster or part of a later spat fall than its larger neighbour (Fig. 2a). Small benthic foraminifera (Planorbinella sp.; compare Hofker 1966) are dotted over the test. A number of pore pairs of mainly the three anterior ambulacra have been altered to single, lensoid pores, by boring barnacles (Rogerella isp.; Donovan and Jagt 2013; Donovan et al. 2016).

\section{Remarks}

What makes a single specimen of a common Late Cretaceous species of irregular echinoid encrusted by a common bivalve worthy of comment? We consider that there are at least four points that make this specimen worthy of special attention.

1. Only one successful encrusting oyster This specimen is an unusual and rare biotic association in the type Maastrichtian (J. W. M. J. and S. K. D., pers. obs.). There is a large, cemented oyster valve on this echinoid and little else. Extant and fossil oysters are commonly, albeit not invariably, gregarious (e.g., Yonge 1960; Stenzel 1971; Littlewood and Donovan 1988), settlement behaviour of larvae being controlled by factors such as high light intensities, food concentrations (Bayne 1969) and chemical cues (Veitch and Hidu 1971; Turner et al. 1994; Vasquez et al. 2013). Although ostreid and gryphaeid oysters are locally common in the Nekum Member, "The upper part of the member (Felder and Bosch 2000, Fig. 3.48) comprises porous, fine-grained carbonate sands, with undulating erosion surfaces" (Jagt and Jagt-Yazykova 


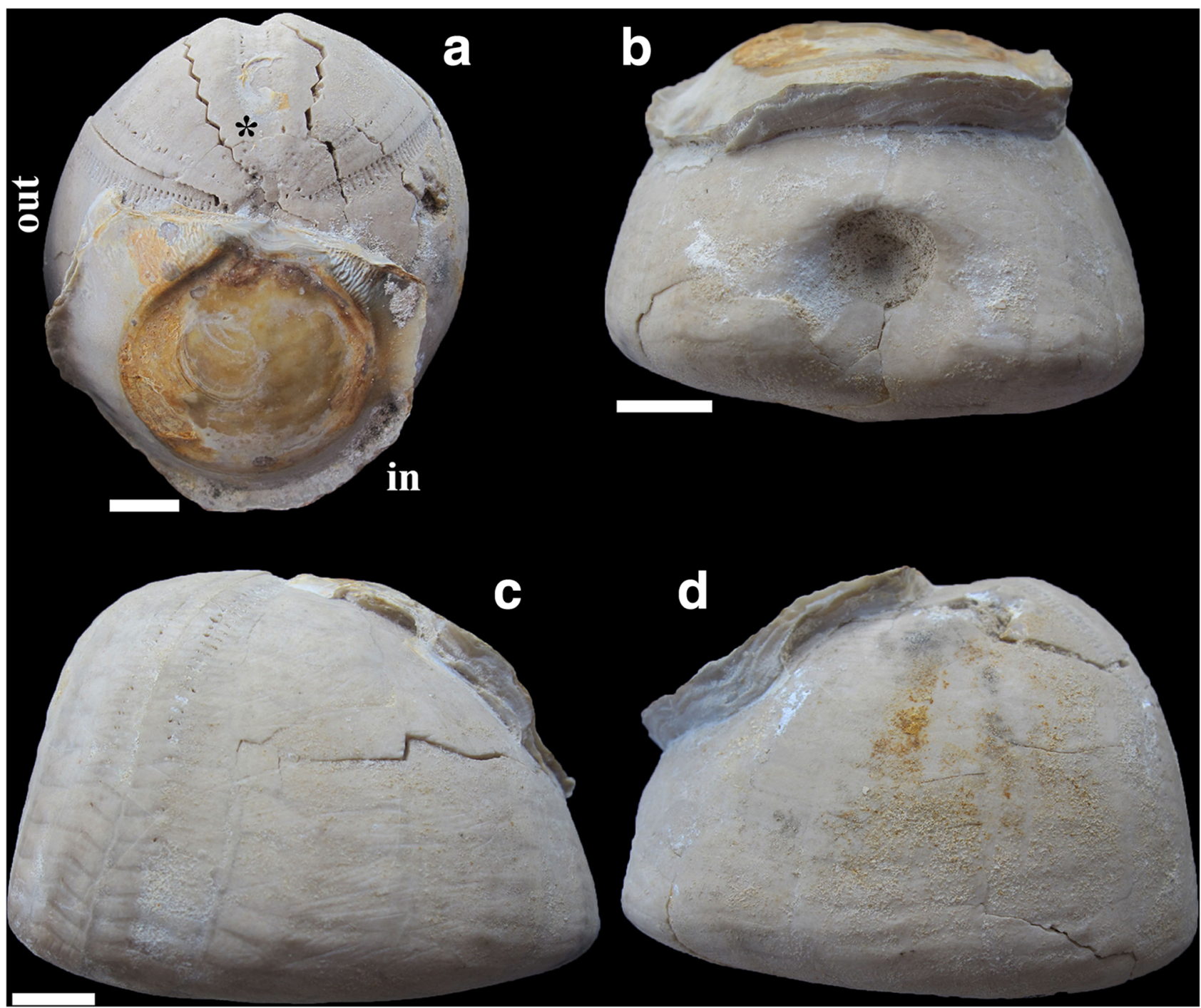

Fig. 2 NHMM BM MK.151, Hemipneustes striatoradiatus (Leske, 1778) encrusted by the left (= attached) valve of Pycnodonte (Phygraea) vesiculare (Lamarck, 1806), from the Nekum Member (Maastricht Formation) of quarry 't Rooth, Bemelen (southern Limburg, the Netherlands). a Apical view, anterior towards top of page. Pycnodonte $(P h$.$) vesiculare attached to posterior of apical$ system and much of the posterior test. The long, straight dorsal margin is arrayed sub-perpendicular to the long axis of the echinoid. For numbering of Hemipneustes ambulacra and interambulacra, see

2012, p. 17), suggesting shallow-water deposition, but possibly in a turbid environment. Chemical cues may have been rapidly dispersed in an energetic environment hostile to larval oysters.

Another contributing factor may have been that high current energy frequently reoriented or overturned exposed echinoid tests. For the oyster to grow to large size, this echinoid may have been unusually stable. This would be analogous to dead tests of Recent Clypeaster rosaceus (Linnaeus, 1758) in the tropical western Atlantic, a large
Donovan et al. (2014, fig. 2a). A small black asterisk marks to positions of the (pale coloured) small oysters in the anterior ambulacrum. 'In' and 'out' mark the approximate incurrent and outcurrent positions of the oyster. (b) Posterior view showing how Pycnodonte (Ph.) vesiculare extended to just above the periproct. (c, d) Left and right lateral views, respectively, showing Pycnodonte $(P h$.$) vesiculare extending across the posterior test. Stated orienta-$ tions refer to the echinoid test. All scale bars represent $10 \mathrm{~mm}$

echinoid commonly found in life position, and abundantly encrusted and bored by invertebrates (S.K.D., pers. obs.).

2. The oyster is large Presumably this indicates a long residence time on the dead test. However, growth rates of one extant oyster as an example, Crassostrea rhizophorae (Guilding, 1828), the West Indian mangrove oyster, vary between 0.1 and $0.5 \mathrm{~mm} \mathrm{day}^{-1}$ (reviewed by Littlewood and Donovan 1988, p. 1023). That is, the individual of $P$. (Ph.) vesiculare on NHMM BM MK.151 could conceivably represent 
growth during only one season. Other $P$. $(P h$. vesiculare in these deposits may attain a comparable size.

3. The oyster cemented high on the echinoid test "Later crawling movements [of oyster larvae] have been described as upwards ... any movement away from possible accumulation of mud could be of value" (Yonge 1960, p. 69). Thus, it is likely that $P$. (Ph.) vesiculare selected this elevated position. However, as it grew, the commissure of the shell would have moved down the shell side towards the sediment surface, assuming the empty echinoid test remained on the seafloor in life position. This seems likely, as the only other bivalve encrusters (Fig. 2a, anterior of apical system) attained even higher positions, just anterior to the highest point on the text. Further, Rogerella isp. and benthic foraminifera are commoner on the upper half of the test (Donovan et al. 2016). These distributions all support an interpretation of the echinoid test resting on its flat and stable oral surface.

4. Was the orientation of the echinoid test favourable to feeding currents? Here we must venture further into the realm of informed speculation. By comparison with feeding currents in a typical extant oyster, Ostrea edulis Linnaeus, 1758 (Yonge 1960, fig. 9), incurrents would have been drawn into the shell from to the right of the echinoid's periproct (Fig. 2b) and expelled parallel to the left anterior petal (ambulacrum IV) (Fig. 2a). As the oyster grew down the posterior test surface of the echinoid, its incurrent water would have come from progressively closer to the sediment surface; that is, incurrent water would have become more sediment laden. The oyster would have benefitted more from having an orientation, for example, rotated through $180^{\circ}$, whereby the shell would have grown onto higher elevations and perhaps become elevated above the shell.

Indeed, why the attached valve is so completely in contact with the echinoid test is uncertain, although comparable conspecific examples are known on tests of Echinocorys of the limburgica and conoidea groups from the Vijlen and Lixhe 1 members, respectively, in the Haccourt-Lixhe area (J. W. M. Jagt, pers. obs.). Cleevely and Morris (2002, p. 147) noted that this species was "Usually with small-medium attachment area ...", whereas this valve has $100 \%$ attachment. The reason for such a large attachment area in this example remains uncertain, but it may be related to a particularly energetic current regime.

In conclusion, the palaeoautecology of a specimen of the large oyster, P. (Phygraea) vesiculare, poses as many questions as it answers. The oyster encrusted a benthic island, namely a dead holasteroid echinoid, $H$. striatoradiatus, but no other members of the same spat fall successfully attached to this test. Indeed, only two other, much smaller conspecific shells attached either then or somewhat later. Although the oyster is large, it may have attained this size in a single season. The larval oyster cemented high on the test, which may have been initially advantageous, but, as it grew, the incurrent margin of the commissure became progressively closer to the sediment surface. That is, as it grew larger, the quality of the incurrent water probably deteriorated as the sediment content of the water increased.

Acknowledgements We thank Els Brock for transfer of the BrockMeessen Collection to the Natuurhistorisch Museum Maastricht, the numerous private collectors who show us their recent finds on a regular basis and the journal reviewers, Professor James R. Thomka (University of Akron, Ohio) and Dr. Timothy A. M. Ewin (Natural History Museum, London), for pertinent comments on an earlier version of the typescript.

\section{References}

Agassiz, L. (1836). Prodrome d'une monographie des radiaires ou échinodermes. Mémoires de la Société des Sciences naturelles de Neuchâtel, 1, 168-199.

Bayne, B. L. (1969). The gregarious behaviour of the larvae of Ostrea edulis L. at settlement. Journal of the Marine Biological Association of the United Kingdom, 49, 327-356.

Belaústegui, Z., De Gibert, J. M., Nebelsick, J. H., Domènech, R., \& Martinell, J. (2013). Clypeasteroid echinoid tests as benthic islands for gastrochaenid bivalve colonization: Evidence from the Middle Miocene of Tarragona, north-east Spain. Palaeontology, 56, 783-796.

Belaústegui, Z., Muñiz, F., Nebelsick, J. H., Domènech, R., \& Martinell, J. (2017). Echinoderm ichnology: Bioturbation, bioerosion and related processes. Journal of Paleontology, 91, 643-661.

Bromley, R. G. (1981). Concepts in ichnotaxonomy illustrated by small round holes in shells. Acta Geològica Hispànica, 16, 55-64.

Cleevely, R. J., \& Morris, N. J. (2002). Introduction to molluscs and bivalves. In A. B. Smith, \& D. J. Batten (Eds.), Fossils of the Chalk. Second and enlarged edition. Palaeontological Association, Field Guides to Fossils (Vol. 2, pp. 98-160).

Lamarck, J. B. A. P. M. de (1806). Mémoire sur les fossiles des environs de Paris, comprenant la détermination des espèces qui appartiennent aux animaux marins sans vertèbres, et dont la plupart sont figurés dans la collection des vélins du Muséum. Annales du Muséum d'Histoire naturelle de Paris, 8, 153-166.

Donovan, S. K. (1991). The taphonomy of echinoderms: Calcareous multi-element skeletons in the marine environment. In $\mathrm{S}$. K. Donovan (Ed.), The Processes of Fossilization (pp. 241-269). London: Belhaven Press.

Donovan, S. K., \& Jagt, J. W. M. (2002). Oichnus Bromley borings in the irregular echinoid Hemipneustes Agassiz from the type Maastrichtian (Upper Cretaceous, The Netherlands and Belgium). Ichnos, 9, 67-74.

Donovan, S. K., \& Jagt, J. W. M. (2013). Rogerella isp. infesting the pore pairs of Hemipneustes striatoradiatus (Leske) (Echinoidea: Upper Cretaceous, Belgium). Ichnos, 20, 153-156. 
Donovan, S. K., Jagt, J. W. M., \& Goffings, L. (2014). Bored and burrowed: An unusual echinoid steinkern from the Type Maastrichtian (Upper Cretaceous, Belgium). Ichnos, 21, 261-265.

Donovan, S. K., Jagt, J. W. M., \& Langeveld, M. (2018). A dense infestation of round pits in the irregular echinoid Hemipneustes striatoradiatus (Leske) from the Maastrichtian of the Netherlands. Ichnos, 25, 25-29.

Donovan, S. K., Jagt, J. W. M., \& Nieuwenhuis, E. (2016). Site selectivity of the boring Rogerella isp. infesting Cardiaster granulosus (Goldfuss) (Echinoidea) in the type Maastrichtian (Upper Cretaceous, Belgium). Geological Journal, 51, 789-793.

Felder, W. M., \& Bosch, P. W. (2000). Geologie van Nederland, deel 5. Krijt van Zuid-Limburg. Delft: Nederlands Instituut voor Toegepaste Geowetenschappen TNO.

Forbes, E. (1850). On Cardiaster, a new genus of Cretaceous Echinidæ, allied to Holaster. Annals and Magazine of Natural History (series 2), 6, 442-444.

Guilding, L. (1828). Observations on the zoology of the Caribbean islands. Zoological Journal, 3, 542.

Hammond, J., \& Donovan, S. K. (2017). Shallow traces (pits) in the test of the irregular echinoid Echinocorys scutata Leske from the Chalk (Upper Cretaceous) of the United Kingdom. Ichnos, 24, 124-132.

Hofker, J. (1966). Maestrichtian, Danian and Paleocene Foraminifera. The Foraminifera of the type-Maestrichtian in South Limburg, Netherlands, together with the Foraminifera of the underlying Gulpen Chalk and the overlying calcareous sediments; the Foraminifera of the Danske Kalk and the overlying greensands and clays as found in Denmark. Palaeontographica, Supplement, 10, $1-376$.

Jagt, J. W. M. (1999a). Late Cretaceous-Early Palaeogene echinoderms and the K/T boundary in the southeast Netherlands and northeast Belgium-Part 1: Introduction and stratigraphy. Scripta Geologica, 116, 1-57.

Jagt, J. W. M. (1999b). An overview of Late Cretaceous and Early Palaeogene echinoderm faunas from Liège-Limburg. Bulletin de l'Institut royal des Sciences naturelles de Belgique, Sciences de la Terre (Belgium, The Netherlands), 69(Supplement A), $103-118$.

Jagt, J. W. M. (2000). Late Cretaceous-Early Palaeogene echinoderms and the K/T boundary in the southeast Netherlands and northeast Belgium-Part 4: Echinoids. Scripta Geologica, 121, 181-375.

Jagt, J. W. M. (2011). Schatten ontsloten: de verzameling BrockMeessen in het Natuurhistorisch Museum Maastricht. Natuurhistorisch Maandblad, 100(12), 258-264.

Jagt, J. W. M., Donovan, S. K., \& Deckers, M. J. M. (2012). Clustered bourgueticrinid crinoid holdfasts on late Maastrichtian echinoids from northeast Belgium and southeast Netherlands. In A. Kroh, \& M. Reich (Eds.), Echinoderm research 2010: Proceedings of the seventh European echinoderm conference, Göttingen, Germany, 2-9 October 2010. Zoosymposia (Vol. 7, pp. 81-90).

Jagt, J. W. M., \& Jagt-Yazykova, E. A. (2012). Stratigraphy of the type Maastrichtian—a synthesis. In J. W. M. Jagt, S. K. Donovan,
\& E. A. Jagt-Yazykova (Eds.), Fossils of the type Maastrichtian (Part 1). Scripta Geologica Special Issue (Vol. 8, pp. 5-32).

Leske, N. G. (1778). Iacobi Theodori Klein naturalis dispositio echinodermatum, edita et descriptionibus novisque inventis et synonymis auctorum et aucta a N. G. Leske (p. xxii). Leipzig: G.E. Beer.

Linnaeus, C. (1758). Systema naturae, per regna tria naturae, secundum classes, ordines, genera, species, cum characteribus, differentiis, synonymis, locis. Editio decima, reformata (Vol. 1, no. 6, p. iv). Stockholm: Laurentius Salvius.

Littlewood, D. T. J., \& Donovan, S. K. (1988). Variation of recent and fossil Crassostrea in Jamaica. Palaeontology, 31, 1013-1028.

Mulder, E. W. A., Jagt, J. W. M., \& Stroucken, J. W. (2016). New records of latest Cretaceous neosuchian crocodyliforms from the Maastrichtian type area (southern Limburg, the Netherlands). In R. M. Sullivan, \& S. G. Lucas (Eds.), Fossil Record 5. New Mexico Museum of Natural History and Science Bulletin (Vol. 74, pp. 169-172).

Nebelsick, J. H., Schmid, B., \& Stachowitsch, M. (1997). The encrustation of fossil and recent sea-urchin tests: Ecological and taphonomic significance. Lethaia, 30, 271-284.

Nestler, H. (1965). Die Rekonstruktion des Lebensraumes der Rügener Schreibkreide-Fauna (Unter-Maastricht) mit Hilfe der Paläoökologie und Paläobiologie. Geologie, Beiheft, 49, 1-147.

Schmid, F. (1949). Orientierte Anheftung von Ostrea vesicularis [sic] Lamarck, Dimyodon nilssoni [sic] Hagenow and Crania parisiensis [sic] Defrance. Mitteilungen aus dem Geologischen Staatsinstitut in Hamburg, 19, 53-56.

Skelton, P. W. (1985). Bivalvia. In J. W. Murray (Ed.), Atlas of Invertebrate Macrofossils (pp. 81-101). Harlow: Longman.

Smith, A. B., \& Wright, C. W. (2002). Echinoderms. In A. B. Smith, \& D. J. Batten (Eds.), Fossils of the chalk (second edition). Palaeontological Association, Field Guides to Fossils (Vol. 2, pp. 251-295).

Smith, A. B., \& Wright, C. W. (2003). British Cretaceous echinoids. Part 7, Atelostomata, Holasteroida. Monograph of the Palaeontographical Society, London, 156(619), 440-568.

Stenzel, H. B. (1971). Oysters. In R. C. Moore (Ed.), Treatise on Invertebrate Paleontology, part N, Mollusca 6, Bivalvia (Vol. 3, pp. N953-N1224). Boulder/Lawrence: Geological Society of America/University of Kansas.

Taylor, P. D., \& Wilson, M. A. (2002). A new terminology for marine organisms inhabiting hard substrates. Palaios, 17, 522-525.

Turner, E. J., Zimmer-Faust, R. K., Palmer, M. A., Luckenbach, M., \& Pentcheff, N. D. (1994). Settlement of oyster (Crassostrea virginica) larvae: Effects of water flow and a water-soluble chemical cue. Limnology and Oceanography, 39, 1579-1593.

Vasquez, H. E., Hashimoto, K., Yoshida, A., Hara, K., Imai, C. C., Kitamura, H., et al. (2013). A glycoprotein in shells of conspecifics induces larval settlement of the Pacific oyster Crassostrea gigas. PLoS One, 8(12), e82358.

Veitch, F. P., \& Hidu, H. (1971). Gregarious settling in the American oyster Crassostrea virginica Gmelin: I. Properties of a partially purified "settling factor". Chesapeake Science, 12, 173-178.

Yonge, C. M. (1960). Oysters (p. xiv). London: Collins. 